\section{Uses of Compost in Potting Mixes}

\author{
Kimberly K. Moore ${ }^{1}$
}

AdDITIONAL INDEX wORDs. recycling, organic matter, urban waste

SumMary. The ornamental horticulture industry uses a variety of materials as ingredients in growing substrates for many ornamental plants. There are many attributes that make growing substrates effective, including good aeration and drainage, availability at an acceptable price, and chemical attributes conducive for plant growth. In recent years there has been a trend in which more traditional organic components, such as Canadian sphagnum peat, have been partially replaced by an increasing array of wasteproduct compost. Plant response to increasing quantities of compost in the potting mix, and to different types of compost are variable. This paper reviews some important issues in the utilization of urban waste compost products.

\section{A} large majority of ornamental crops are grown in containers and when the crop is sold, the growing substrate is sold with it. This necessitates the continuous acquisition of growing substrate for each production cycle. In general, growers look for substrates that are consistent, reproducible, available, easy to mix and handle, cost effective, and have the appropriate physical and chemical properties for their specific crop (Poole et al., 1981). To achieve these goals, growers combine different types and amounts of organic and inorganic components. Most growing substrates contain between $20 \%$ to $100 \%$ organic matter in the mix, depending on the plant being grown (Whitcomb, 1988). Because of the continuous requirement for organic matter as a component of the growing substrate, this creates unique opportunities for the development and utilization of compost

\footnotetext{
${ }^{1}$ Associate Professor, University of Florida, Fort Lauderdale Research and Education Center, 3205 College Ave., Fort Lauderdale, FL 33314

Florida Agricultural Experiment Station journal series no. R-09842. Mention of any trade names does not imply endorsement of the products named or criticism of similar ones not named.
}

products derived from urban waste as components in the growing substrate (Fitzpatrick, 2001).

\section{Plant responses to compost}

There are many opinions about the use of compost in the growing substrate for ornamental plants. Compost can be used as a stand-alone substrate, a component of the growing substrate, an organic top dress, or as an incorporated soil amendment (Fitzpatrick, 1998). Generally, compost has been used as a component in the growing substrate for container production as a less expensive alternative to peat and other organic components. The goal in using compost in the growing substrate is to use enough to get the desired growth effect at a cost-effective price. The question arises as to how much compost to use in the growing substrate because plant response varies among different compost products as well as with different compost incorporation rates in the substrate.

Research has been conducted on annual, perennial, and woody ornamental plant responses to increasing concentrations of different compost products in the growing substrate. Five basic patterns become evident when reviewing the literature about compost use in container production: 1 ) no response, 2) plateau, 3) linear increase, 4) bell curve, or 5) decrease (Fig. 1).

Some plants show no response to increasing percentages of compost in the growth substrate (Fig. 1A). Plants grown in containers containing compost are equal in size and quality to plants grown in substrates condecrease. taining no compost. For example, Klock-Moore (1999) noted that there was no difference in begonia (Begonia $\times$ semperflorens-cultorum) or impatiens (Impatiens wallerana) shoot dry weight between the control substrate (60\% Canadian sphagnum peat, $25 \%$ vermiculite, $15 \%$ perlite by volume) and substrates containing $30 \%, 60 \%$,

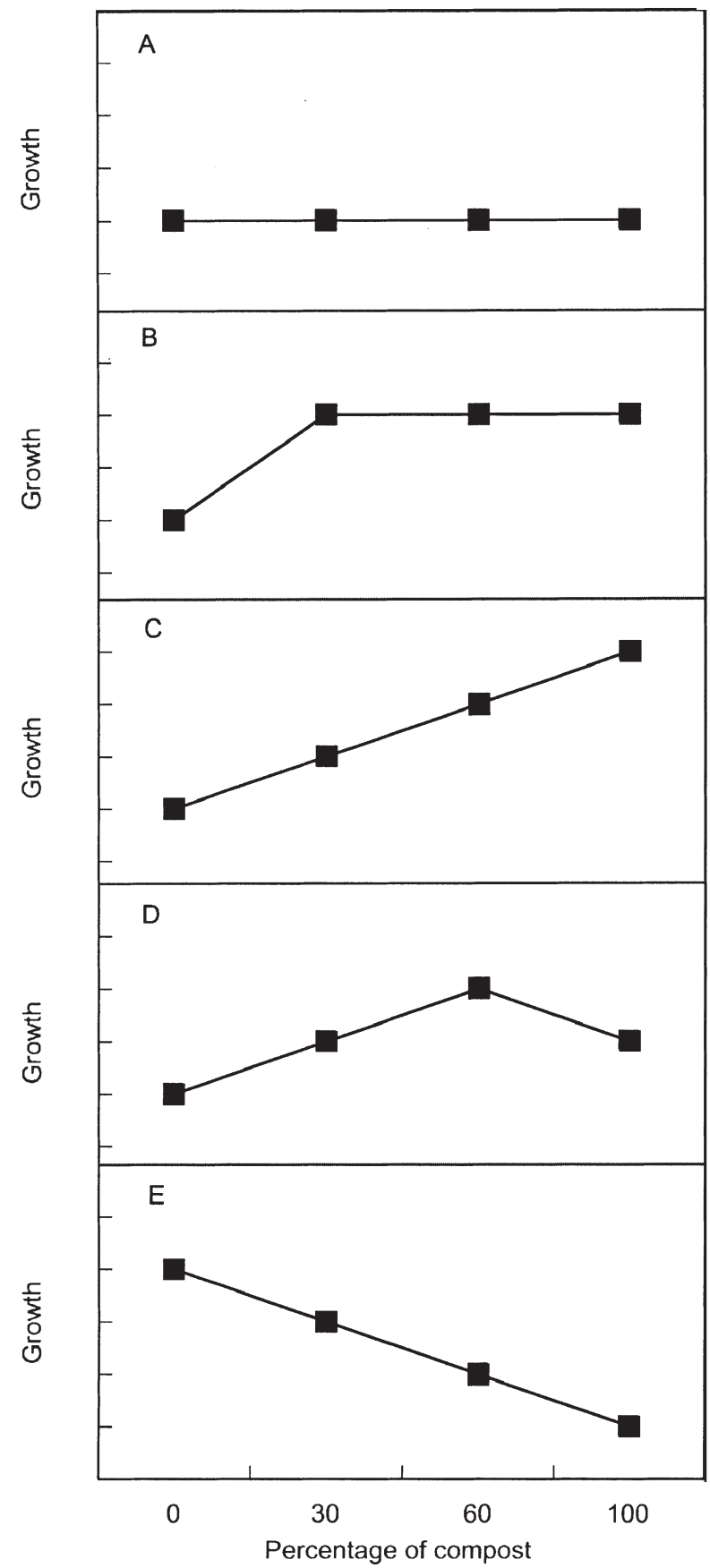

Fig. 1. Five plant responses to increasing percentages of composted urban waste in the growing substrate of container grown plants: (A) no response, (B) plateau, (C) linear increase, (D) bell curve, and (E) 
or $100 \%$ compost made from recycled greenhouse media and yard trimmings. Klock and Fitzpatrick (1997) also reported that impatiens shoot dry weight of plants grown in $30 \%, 60 \%$, and $100 \%$ composted refuse derived fuel residues was similar to control plants. Similarly, growth of 'Red Hot Sally' salvia ( Salvia splendens) plants in $30 \%, 60 \%$, and $100 \%$ compost made from seaweed and yard trimmings was similar to control plants (Klock-Moore, 2000). Growth of jasmine (Jasmine volubile) plants in the control substrate [ 6 peat: 4 sawdust : I sand (by volume)] also was similar to growth in $80 \%$ biosolids compost (Fitzpatrick, 1981) and viburnum (Viburnum suspensum) plants grown in $40 \%$ and $100 \%$ municipal solid waste compost were not significantly different from control plants (Fitzpatrick and Verkade, 1991). Fitzpatrick (2001) characterized these plants as ambivalent species because changes in the growing substrate did not influence plant growth while other species are responsive to even slight differences in the growing substrate.

The second response group is characterized as a plateau in which plant growth increases as the percentage of compost in the growing substrate increases up to a point with no further increases at higher percentages (Fig. 1B). Plants grown in substrates containing compost are larger or better quality than plants grown in control substrates. For example, Bugbee and Frink (1989) reported that shoot dry weight of 'Lemondrop' marigold (Tagetes erecta) plants grown in substrates containing $10 \%, 20 \%, 30 \%, 40 \%$, and $50 \%$ composted sewage sludge was greater than control plants but were not different from one another. Raymond et al. (1998) observed that deutzia (Dentzia gracilis), silver leaf dogwood (Cornus alba 'Elegantissima), red-osier dogwood (Cornus sericea), and ninebark (Physocarpus opulifolius) growth was greater in growing substrates containing 25\% waxed corrugated cardboard compost than control substrates. Growth of dwarf oleander (Nerium oleander) plants in $100 \%$ municipal solid waste and $100 \%$ paper mill sludge also was significantly greater than the control (Fitzpatrick, 1989).

Other crops show a linear increase in which plant growth increases as the percentage of compost in the substrate increases (Fig. 1C). For example, impatiens, begonia, and snapdragon (Antirrbinum majus) shoot dry weight increased as the percentage of biosolid and yard trimming compost increased from $0 \%$ to $100 \%$ in the growing substrate (Klock, 1997a; Klock-Moore, 1999; Klock and Fitzpatrick, 1997). Chong et al. (1991) reported that the shoot and root dry weight of dogwood 'Argenteo-marginata' and ninebark increased linearly as the percentage of three sources of mushroom compost increased in the growing substrates from $0 \%, 33 \%, 67 \%$, to $100 \%$. Similarly, Beeson (1996) observed that rhododendron (Rhododendron indicum) 'Sweet Duc du Rohan' and pittosporum (Pittosporum tobira variegate) shoot dry weight increased as composted yard waste was mixed with pine bark and coarse sand in increasing concentrations $(0 \%, 40 \%, 60 \%$, $80 \%)$. These increases have typically been the result of increased nutrient concentrations in substrates containing compost.

Some crops show an increase in growth as the percentage of compost in the substrate increases up to a point and then growth decreases as the percentage of compost increases beyond that point (bell curve) (Fig. 1D). As the percentage of some compost products in the substrate increase above $50 \%$, plant growth decreases as a result of high soluble salt concentrations, poor aeration, heavy metal toxicity, and/or phytotoxicity (Shiralipour et al., 1992). For example, salvia, dianthus (Dianthus chinensis), and petunia (Petunia $x$ bybrida) shoot dry weight increased as the percentage of biosolid and yard trimming compost increased from $0 \%$ to $60 \%$ and then decreased (KlockMoore, 2000; Klock, 1997b). Zinnia (Zinnia elegans) 'Fire Cracker' and marigold 'Golden jubilee' shoot dry weight increased as percentage of a fine [compost particles between 0 and 2.4 $\mathrm{mm}(0.094$ inch $)$ ] composted sewage sludge and wood chips increased from $0 \%$ to $25 \%$ but decreased at percentages greater than $50 \%$ (Wootton et al., 1981). Similarly, shoot dry weight of marigold 'Lemondrop' plants grown in a pharmaceutical and a cranberry compost increased as percentage of compost increased from $0 \%$ to $10 \%$ and $40 \%$, respectively, and then decreased (Bugbee and Frink, 1989).

Finally, plant growth may decrease as the percentage of compost in the growing substrate increases (Fig. 1E).
For example, Klock and Fitzpatrick (1997) observed that impatiens shoot dry weight decreased as the percentage of composted municipal solid waste increased from $0 \%$ to $100 \%$. Wilson et al (2001) reported that cat whiskers (Orthosiphon stamineus), angelonia (Angelonia angustifolia), golden shrimp plant (Pachystachys lutea), and golden globe (Lysimachia congestiflora) shoot dry weight was similar in substrates containing $0 \%$ and $25 \% \mathrm{com}$ posted biosolids and yard trimmings but decreased at concentrations of biosolids and yard trimmings compost greater than $50 \%$ or $75 \%$. They also observed that mexican heather $(\mathrm{Cu}$ phea hyssopifolia) and bolivian sunset (Gloxinia sylvatica) shoot dry weight decreased as percentage of composted biosolids and yard trimmings increased from $0 \%$ to $100 \%$ (Wilson et al., 2001). Sanderson (1980) observed that chrysanthemum (Chrysanthemum $\times$ morifolium), snapdragon, and geranium (Pelargonium $\times$ hortorum) plants produced less dry weight when grown in a sewage refuse substrate than when grown in a sphagnum peat moss substrate. Broschat (1991) reported that queen palms (Syagrus romanzoffiana) grown in several types of sewage sludge compost developed severe manganese $(\mathrm{Mn})$ deficiency and were shorter than control plants. The examined sewage sludge compost bound Mn so tightly that susceptible plants developed Mn deficiency (Broschat, 1991). The decrease in plant growth due to increasing concentrations of compost in the substrate is frequently the cause of immature and/or poor compost quality. Typically immature and poor quality compost products have supra-optimum or sub-optimum carbon: nitrogen ratios, high soluble salt concentrations, high concentrations of organic acids and other phytotoxic compounds, high microbial activity, and high respiration rates (Jimenez and Garcia, 1989).

\section{Conclusion and recommendation}

It is obvious from the research that plant response varies with the amount of compost in the growing substrate as well as with the type of compost being used. Compost products can vary. Before a grower invests in using compost in their container substrate they need to know l) what parent materials were used to make the compost, 
Table 1. Optimal values and ranges for several parameters that are measured in compost products to judge their suitability for use as a component of the growing substrate for container-grown plants (Rynk et al., 1992).

\begin{tabular}{ll}
\hline Parameter measured & \multicolumn{1}{c}{ Optimal value or range } \\
\hline Particle size & $\begin{array}{c}\text { Compost screened to pass through a } 0.5 \text { - to } 0.75 \text {-inch } \\
\text { screen }\end{array}$ \\
& 5.0 to 7.6 \\
pH & $<2.5 \mathrm{dS} \cdot \mathrm{m}^{-1}$ (based on a SME test) \\
Soluble salt concn & $<20$ \\
Carbon : nitrogen & $5 \%$ to $30 \%$ \\
Air-filled porosity & $20 \%$ to $60 \%$ \\
Water-holding capacity & $<1 \%$ dry weight \\
Foreign material & Notexceeding U.S. Environmental Protection Agency (EPA) \\
Heavy metals & standards \\
& $<200 \mathrm{mg} \cdot \mathrm{kg}^{-1}(\mathrm{ppm})$ oxygen consumed per hour \\
\hline
\end{tabular}

${ }^{\mathrm{z}} 1$ inch $=2.54 \mathrm{~cm}$

${ }^{y} 1 \mathrm{dS} \cdot \mathrm{m}^{-1}=1 \mathrm{mmhos} \cdot \mathrm{cm}^{-1}=670 \mathrm{ppm} ; \mathrm{SME}=$ saturated media extraction.

2) any pre-processing that may have been done, 3 ) what if any post-processing was done, 4) composting time, 5 ) compost maturity, 6) content of inert materials, 7) concentrations of heavy metals, and 8 ) physical and chemical properties of the compost (Fitzpatrick, 1998). For example, Fitzpatrick (1986) reported that spathiphyllum (Spathiphyllum spp.) 'Mauna Loa' and schefflera (Schefflera arboricola) plants grown in composts that had sludge that had been stabilized by treatment with ferric chloride and lime were smaller than plants grown in composts with sludge that had been stabilized using wet air oxidation. The ferric chloride and lime sludge stabilization process produced a finished compost product that had significantly higher soluble salt concentrations than the wet air oxidation stabilized sludge. Table 1 outlines some general guidelines of compost that are suitable for use in container production (Rynk et al., 1992).

Commercial composting organizations must consistently produce a product that can be successfully used in container production through careful monitoring and management. Growers need to be aware that the appropriate amount of compost to use in their container substrate will vary with the plant being grown as well as with the type of compost. It is difficult to recommend one compost product over another. Growers should choose compost products that will meet the physical and chemical parameters of the crop that they are growing.

\section{Literature cited}

Beeson R.C. Jr. 1996. Composted yard waste as a component of container substrates. J. Environ. Hort. 14(3):115121 .

Broschat, T.K. 1991. Manganese binding by municipal waster composts used as potting media. J. Environ. Hort 9:97-100.

Bugbee, G.J. and C.R. Frink. 1989. Composted waste as a peat substitute in peat-lite media. HortScience 24(4):625-627.

Chong, C., R.A. Cline, D.L. Rinker, and O.B. Allen. 1991. Growth and mineral nutrient status of containerized woody species in media amended with spent mushroom compost. J. Amer. Soc. Hort. Sci 116(2):242-247.

Fitzpatrick, G.E. 1981. Evaluation of potting mixes derived from urban waste products. Proc. Fla. State Hort. Soc. 94:95-97.

Fitzpatrick, G.E. 1986. Sludge processing effects on compost quality. BioCycle 27(9):32-35.

Fitzpatrick, G.E. 1989. Solid waster composts as growing media. BioCycle 30(9):62-64.

Fitzpatrick, G.E. 1998. Compost and quality assurance. p. 21-23. In: D. Tonnessen (ed). Compost use in Florida. Florida Dept. of Environ. Protection, Tallahassee.

Fitzpatrick, G.E. 2001. Compost utilization in ornamental and nursery crop production systems, p.135-150. In: P.J. Stoffella and B.A. Kahn (eds.). Compost utilization in horticultural cropping systems. Lewis Publ., Boca Raton, Fla.

Fitzpatrick, G.E. and S.D. Verkade. 1991. Substrate influence on compost efficacy as a nursery medium. Proc. Fla. State Hort. Soc. 104:308-310.
Jimenez, E.I. and V.P. Garcia. 1989. Evaluation of city refuse compost maturity: A review. Biolog. Wastes 27:115-142.

Klock, K.A. 1997a. Growth of salt sensitive bedding plants in media amended with composted urban waste. Compost Sci. Utilization 5(3):55-59.

Klock, K.A. 1997b. Growth of dianthus and petunia in media amended with composted urban waste. J. Environ. Hort. 15(3):135-137.

Klock, K.A. and G.E. Fitzpatrick. 1997. Growth of impatiens 'Accent Red' in three compost products. Compost Sci. Utilization 5(4):26-30.

Klock-Moore, K.A. 1999. Bedding plant growth in greenhouse waste and biosolid compost. HortTechnology 9(2):210-213.

Klock-Moore, K.A. 2000. Comparison of salvia growth in seaweed compost and biosolids compost. Compost Sci. Utilization 8(1):24-28.

Poole, R.T., C.A. Conover, and J.N. Joiner. 1981. Soils and potting mixtures, p. 179-202. In: J.N. Joiner (ed.). Foliage plant production. Prentice Hall, Englewood Cliffs, N.J.

Raymond, D.A., C. Chong, and R.D. Voroney. 1998. Response of four container grown woody ornamentals to immature composted media derived from waxed corrugated cardboard. Compost Sci. Utilization 6(2):67-74.

Rynk, R., M. van de Kamp, G.G. Willson, M.E. Singley, T.L. Richard, J.J. Kolega, F.R. Gouin, L. Laliberty, Jr., D. Kay, D.W. Murphy, H.A.J. Hoitink, and W.F. Brinton. 1992. On-farm composting handbook. Northeast Reg. Agr. Eng. Serv., Ithaca, N.Y.

Sanderson, K.C. 1980. Use of sewage-refuse compost in the production of ornamental plants. HortScience 15:173-178.

Shiralipour, A., D.B. McConnell, and W.H. Smith. 1992. Uses and benefits of MSW compost: A review and an assessment. Biomass Bioenergy 3:267-279.

Whitcomb, C.E. 1988. Plant production in containers, Lacebark Publ., Stillwater, Okla.

Wilson, S.B., P.J. Stoffella, and L.A. Krumfolz. 2001. Containerized perennials make good use of compost. BioCycle 42(8):59-60.

Wootton, R.D., F.R. Gouin, and F.C. Stark. 1981. Composted, digested sludge as a medium for growing flowering annuals. J. Amer. Soc. Hort. Sci. 106:46-49. 